\title{
一般 42
}

\section{若年発症の高尿酸血症・痛風により判明した Lesch-Nyhan-variantの一家系症例}

\section{症例}

19 歳男性. 高校生の頃より痛風と考えられる 拇趾関節の疼痛を自覚していたが自然軽快するた め放置していた。 20XX年 $\mathrm{X}$ 月痛風発作にて近医 を受診し採血にて尿酸 $10.9 \mathrm{mg} / \mathrm{dl}$ と高值であった がその後受診が無く，半年後の採血で $13.4 \mathrm{mg} / \mathrm{dl}$ まで増加していたため紹介医を受診された。治療 を行い改善傾向にはあったものの肥満や甲状腺機 能異常, 生活習慣の偏りもなく, 患者を含む男性 同胞 3 人が同様の高尿酸血症・痛風を発症し, 長 男には発達障害もあったため遺伝的素因を含め精 査・加療目的に当院紹介となった.

\section{目的}

若年で高尿酸血症・痛風を発症した患者・同胞 に対して鑑別として挙がるHPRT 欠損症の可能性 について遺伝的素因の影響も含めて精査を行う.

\section{方 法}

患者・家族の末梢血よりゲノムDNAおよび mRNAを抽出し，PCR法を用いて全エクソンを 増幅, また mRNAから RT-PCR法により cDNA を増幅して, 直接塩基配列決定法を用いて遺伝子

\begin{tabular}{|c|c|c|c|}
\hline 安史1） & & 慎治 ${ }^{1)}$ & 山内 高弘 1 \\
\hline 明1) & 上田 & 孝典 ${ }^{1)}$ & 裕一2) \\
\hline $\begin{array}{ll}\text { 三澤 } & \left.\text { 美和 }{ }^{3}\right) \\
\text { 市田 } & \text { 公美4) }\end{array}$ & 江川 & 克哉3) & 中村真希子 4) \\
\hline
\end{tabular}

変異を同定する。また，同時に赤血球中の HPRT，APRT活性やPRPP濃度等も測定する。

\section{結 果}

患者・同胞全員から HPRT 遺伝子の第 2 エクソ ンで59番目の塩基 $\mathrm{A}$ が $\mathrm{T} に$ 変わる一塩基置換 （59A $>\mathrm{T} ）$ が検出され，20番目のアミノ酸がアス パラギン酸からバリンに変わるミスセンス変異 （D20V）が同定された，母親には正常ゲノムと変 異ゲノムの両方が認められたためへテロ接合体で 保因者と考えられ，患者・同胞は変異アリルを含 むX染色体を受け継いでいることが判明した。ま た，母親の HPRT活性は正常であったのに対し， 患者の活性は検出感度以下であった。患者・同胞 で測定した赤血球PRPP濃度も健常男性のものと 比較して高值であり, コントロールとの対比の結 果HPRT部分欠損症と診断された.

\section{考察}

この遺伝子変異は1991年に欧米でLeschNyhan-variant の原因変異として一例報告があり, 本症例は本邦では初の報告になると考えられる.
1 ) 福井大学 内科学 (1)

2 ) 愛知県心身障害者コロニー発達障害研究所

3 ）長浜赤十字病院 糖尿病 - 内分泌内科

4 ) 東京薬科大学 病態生理学教室
Yasufumi Matsuda, Shinji Kishi, Takahiro Yamauchi, Akira Yoshida, Takanori Ueda Yasukazu Yamada Miwa Misawa, Katsuya Egawa Makiko Nakamura, Kimiyoshi Ichida 